\title{
An Ayurvedic Management of Cholelithiasis- A Case Report
}

\author{
Case Report
}

Prakash Ashok Kumbar1 $^{*}$, Garima Singh'2, Lokeshkumar Rajput ${ }^{2}$

1. Associate Professor \& HOD, 2. PG Scholar, Department of Kayachikitsa, Parul Institute of Ayurveda, Parul University, Vadodara.

\begin{abstract}
Background: There are several diseases which arise in gall bladder and one of them is gall stones (cholelithiasis). The prevalence rate is difficult to work out because calculous disease is often asymptomatic. Cholelithiasis has become one among the foremost common diseases of the biliary tract. approximately 80 percent of gallstones contain cholesterol and therefore the remaining 20 percent are pigment stones, which consist mainly of calcium bilirubinate. Case Report: A 35-year male patient approached complaints of heaviness of abdomen, mild intermittent abdomen pain, nausea and with ultrasonography report which was suggestive of cholelithiasis of $4.7 \mathrm{~mm}$. Conclusion: The patient was diagnosed as Pittashmari and treated with ayurvedic medicine. With the help of Ayurvedic treatment protocol, the patient was free from $4.7 \mathrm{~mm}$ cholelithiasis within 2 months of treatment and also improvement was observed in symptoms like the heaviness of the abdomen, pain in the abdomen, and nausea.
\end{abstract}

Key Words: Cholelithiasis, Pittashmari, Cholesterol Stones, Mixed Stones, Arogyavardini.

\section{Introduction}

There are several diseases which arise in gall bladder and one of them is gall stones (cholelithiasis). The prevalence of gall stone disease is more common within the western society. In India, it's more common in women in north, north-east and east as compared to other zones within the country. In children, the gallbladder stone found in approximately $5 \%$, between $30-69$ years aged the prevalence is up to $10 \%$ in male and $19 \%$ in females and increase in $70-80$-year-old people to $30-40 \%$ (1). The prevalence rate is difficult to work out because calculous disease is often asymptomatic (2). There are two sorts of gallstones, among them approximately 80 percent of gallstones contain cholesterol and therefore the remaining 20 percent are pigment stones, which consist mainly of calcium bilirubinate. There are two subtypes of cholesterol gall stones: cholesterol stone (which contain $90-100 \%$ of cholesterol) and mixed stones (which contain 50-90\% cholesterol) (3). Most of the people with gallstones never have symptoms (4) and in some cases the clinical presentations can vary from dyspepsia to severe forms like pancreatitis and perforation of the gall bladder (5).

Perhaps few drugs are there in modern medicine which one reported their activity to dissolve the gall stones with few extents but these are with harmful

\section{* Corresponding Author:}

Prakash Ashok Kumbar

Associate Professor \& HOD,

Department of Kayachikitsa,

Parul Institute Of Ayurveda, Parul University,

Vadodara. India.

Email Id: drprakash.kc@gmail.com adverse effect. e.g., chenodeoxycholic acid ursodeoxycholic acid. Cholelithiasis has become one among the foremost common diseases of the biliary tract. Though it is often managed conservatively, some of the cases need surgical intervention. This might further cause other complications and chances of recurrence also are present. The treatment of choice is at the present only surgical management that's open, minimal access surgery and laparoscopic cholystectomy. There's got to avoid surgery and harmful effect of medicine, therefore the conventional eco-friendly herbal \& natural preparation are being search \& scrutinized as alternative.

\section{Case Presentation \\ Case History}

A 35-year male patient who has approached the general hospital on March 1st,2020 with complaints of mild pain in the abdomen, heaviness of the abdomen after food, and nausea. He has advised some symptomatic treatment and suggested undergoing for USG abdomen which was suggestive cholelithiasis. The physician has prescribed ursodiol $150 \mathrm{mg}$ for 1 month. A patient was not willing to take allopathy medication, he reported for Ayurvedic treatment to Kayachikitsa OPD of Parul Ayurveda Hospital with USG abdomen report which was done on 2 March 2020.

Past medical history suggestive of viral encephalitis in 2015 and was admitted in military command hospital Bangalore and was treated for the same. During that period, patient investigations were also suggestive of hepatitis $B$ infection and he is on medication for the same till now. Personal history was suggestive of alcohol once in 15 days and smoking occasionally from last 10-12 years. 
On General examination. Vital signs revealed normal blood pressure, pulse, temperature, and respiratory rate. Abdominal examination revealed mild tenderness on deep palpation at the right upper quadrant and negative Murphy's sign

\section{Ayurvedic Intervention}

As per etiology, clinical presentation, and investigation reports patient was diagnosed with cholelithiasis. It can be corrected to Pittashmari. Considering the facts following line of treatment was planned for the patient. The patient was prescribed Patolakaturohinyadi Kashaya $10 \mathrm{ml}$ two times a day with an equal quantity of warm water before food and Arogyavardini Vati one tablet two times a day with warm water after food for one month. As lockdown was announced on 22 March 2020, the patient did not come for the follow-up to the hospital. The patient was consulted on phone and advised to continue the same medication. During lockdown he did not get Arogyavardini Vati. As he was purchased an extra bottle of Patolakaturohinyadi Kashaya before lockdown he was advised to continue the same medicines for next a month.

Table 1: Details of treatment given during two months

\begin{tabular}{|c|c|c|c|}
\hline Medicine & Dose & Anupana & Duration \\
\hline $\begin{array}{l}\text { Patolkaturo } \\
\text { hinyadi } \\
\text { Kashaya }\end{array}$ & $\begin{array}{l}10 \mathrm{ml} \text { two } \\
\text { times a day }\end{array}$ & Warm water & 2 months \\
\hline $\begin{array}{l}\text { Arogyavard } \\
\text { ini vati }\end{array}$ & $\begin{array}{l}1 \text { tab two } \\
\text { times a day }\end{array}$ & Warm water & 1 month \\
\hline
\end{tabular}

\section{Results}

After completing two months of medicine course, the patient was called to discuss the further line of treatment. Because of the Covid-19 pandemic and non-availability of medicines, the patient did not continue medicines after two months. Improvement was observed in the symptoms like the heaviness of the abdomen, nausea, and digestion. The patient was advised to undergo USG abdomen once the covid-19 pandemic crisis over. The patient did not receive any other medicines for the above-said complaints and cholelithiasis during the period from May to December 2020.

Table 2: Status of cholelithiasis before and after treatment.

\begin{tabular}{|c|c|c|}
\hline $\begin{array}{l}\text { Before } \\
\text { treatment } \\
\text { March 2, 2020 } \\
\text { (IMAGE 1) }\end{array}$ & $\begin{array}{l}\text { Because of } \\
\text { Covid-19 } \\
\text { pandemic }\end{array}$ & $\begin{array}{l}\text { After treatment } \\
\text { Dec } 12,2020 \\
\text { (IMAGE 2) }\end{array}$ \\
\hline $\begin{array}{l}\text { Single } 4.7 \mathrm{~mm} \\
\text { soft sludge/ } \\
\text { calculus noted in } \\
\text { GB }\end{array}$ & $\begin{array}{l}\text { did not visit the } \\
\text { hospital for } \\
\text { investigation }\end{array}$ & $\begin{array}{l}\text { Normal GB Wall } \\
\text { noted. No soft } \\
\text { calculus or } \\
\text { sludge }\end{array}$ \\
\hline
\end{tabular}

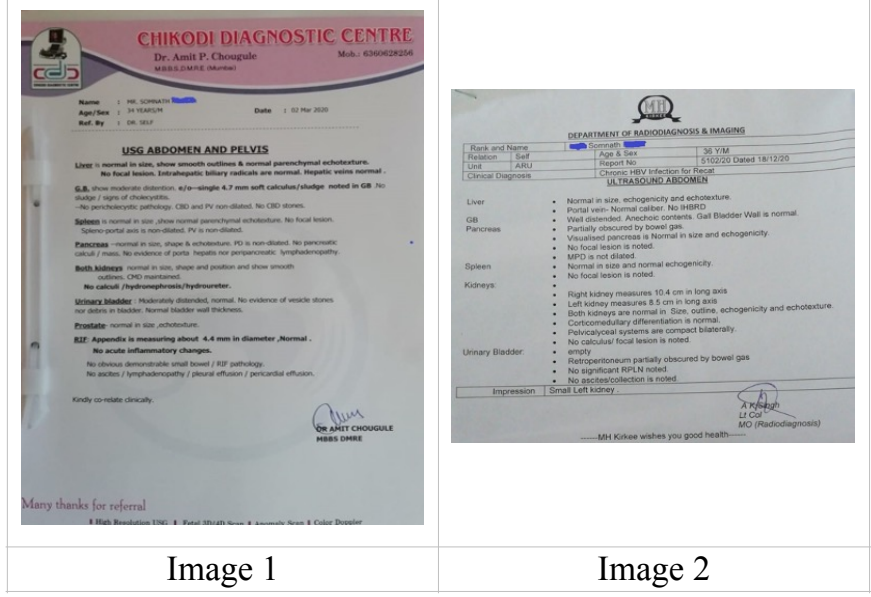

Table 3: Subjective Parameters Assessment

\begin{tabular}{|c|c|l|c|c|}
\hline $\begin{array}{c}\text { Sr } \\
\text { no }\end{array}$ & Symptoms & Grading & BT & AT \\
\hline 1 & $\begin{array}{l}\text { Heaviness } \\
\text { of the } \\
\text { abdomen }\end{array}$ & $\begin{array}{l}\text { 0-No heaviness after } \\
\text { taking food } \\
\text { 1-Mild heaviness after } \\
\text { taking food } \\
\text { 2-Moderate after taking } \\
\text { food } \\
\text { 3- Severe after taking } \\
\text { food }\end{array}$ & 2 & 0 \\
\hline 2 & Nausea & $\begin{array}{l}\text { 0-No nausea } \\
\text { 1-Mild nausea not } \\
\text { requesting } \\
\text { pharmacological rescue } \\
\text { 2-Modeare nausea } \\
\text { requesting } \\
\text { pharmacological rescue } \\
\text { 3-Severe resistant to } \\
\text { pharmacological rescue }\end{array}$ & 1 & 0 \\
\hline 3 & $\begin{array}{l}\text { 0-No pain } \\
\text { 1-Mild pain } \\
\text { 2-Moderate pain } \\
\text { 3-Severe pain }\end{array}$ & 1 & 0 \\
\hline
\end{tabular}

\section{Discussion}

In humans, bile is produced continuously by the liver (liver bile) and stored and concentrated within the gallbladder. After eating, stored bile is discharged into the duodenum and helps in emulsification of fat. It contains water, bile salts, bilirubin, fats (6) and inorganic salts(7), 97-98\%, $0.7 \%, 0.2 \%, 0.51 \%$ and $200 \mathrm{meq} / 1$ respectively. the pigments of bile are bilirubin and biliverdin. About 400 to 800 milliliters of bile is produced per day in adult human beings(8). Bile acid pool consists of primary bile acids (cholic acid, CA, and chenodeoxycholic acid, CDCA) and secondary bile acids (deoxycholic acid, DCA, and lithocholic acid, LCA)(9) Bile acids, phospholipids, and cholesterol are three major organic solutes of the bile and once secreted, they form mixed micelles to extend cholesterol solubility and reduce their toxicity to the common bile duct. Normal bile formation depends largely on balanced secretion of those constituents. Impaired secretions will disrupt the bile flow and result in cholestasis or cholesterol gallstone 
disease(10). The traditional classification scheme classified gallstones into 3 types according to cholesterol content, including cholesterol stone (cholesterol content $\geq 70 \%$ ), pigment stone (cholesterol content $\leq 30 \%)$ and mixed stone $(30 \%$ $\leq$ cholesterol content $\leq 70 \%)(11)$ and these stones can be corelated with the Pittashmari as explained in Ayurveda.

In Ayurveda, three dosha's play an important role in the manifestation of any disease in the body. Similarly, dosha's also have role in cholelithiasis disease. As explained in classics, rakta dhatu and pitta dosha have ashrasya ashyayi relation. Liver is a mula stana for the rakatvaha srotas. So, bile which is secreted from the hepatocytes is stored in the gall bladder and that can be considered as Acchapitta, due to the similarity in the location and function. The qualities of pitta depend on the functions of the liver i.e., Metabolism of cholesterol, bile acids and phospholipids. Gall bladder stores and excretes the bile whenever there is need and plays important role in the digestion process as pitta has important role in the pachankriya. So, it can be considered as representative of pitta.

The qualities of the pitta are sa-sneha, tikshna, ushna, sara and drava. Sa-sneha quality of pitta indicates the consistency of it and it may depend on the concentration of the cholesterol in bile. The ushna- tikshna property of pitta depends on the bile acids percentage in bile and sara and drava depends on the water content of bile. If there is increase in ushna- tikshna guna of pitta it dries up the Sneha and produces the pittashmari which will be dark in color and hard in consistency.

As Sa-sneha guna of pitta depends on the percentage of cholesterol in the bile pool and its metabolism mainly takes place in the liver. So, disturbed metabolism of lipid leads increase in the cholesterol and formation of the gall stones possibilities increases, which can corelated with the Kaphanubanda pitta and increased cunctation of pitta and its precipitation forms the pittashmari which can be corelated with cholesterol stones of gall bladder.

A patient was a known case of hepatitis B and cholelithiasis, drug selected should pose the properties of hepatoprotective and lipid-lowering activities by correcting the lipid metabolism. Considering all these points, the drugs selected for the treatment were Patolkaturohinyadi Kashaya and Arogyavardini vati. Patola Katurohinyadi Kashayam(12) is a classical Ayurvedic herbal formulation explained in Ashtanga Hridaya and which has been used by Ayurvedic practitioners in the management of pitta vikaras and liver disorders. It contains 6 ingredients those are Patola (Trichosanthes dioica Roxb), Katurohini (Picrorhiza kurroa Royle Ex Bonth), Raktachandan (Pterocarpus Santalinus L), Murva (Marsdenia tenacissima Roxb), Guduchi (Tinospora Cordifolia) and Patha (Cissampelos pareira var. hirsuta). The main properties of all these herbal medicines are Pittagna,
Kamalahar, Vishagna, and Raktaprasadhak. Another formulation that was used in patient was Arogyvardini vati. It contains $50 \%$ P. kurroa was also found effective in a double-blind trial in viral hepatitis(13). Patola (Trichosanthes dioica) is proved for its hepatoprotective and lipid lower property. Hepatoprotective activity of the patola was assessed based on the reduction in ALT, AST, and ALP towards normal values by the administration of the extract (ETD) which indicates the repairment of hepatocytes and histopathological study in animals also evidenced the damaged liver toward normalization(14). Mechanism of the lipidemic lowering activity of TD could be the inhibition of lipid absorption due to the presence of saponins and tannins in the aqueous extract(15). P. kurroa contains iridoid glycosides (including picroside I, II, III, pikuroside, kutkoside, and 6-feruloyl catalpol), cucurbitacin glycosides, androsin, apocynin, and other organic acids such as vanillic and cinnamic acids. It is pertinent to notice its ayurvedic properties of tikta rasa, laguruksha guna, and katuvipaka. Based on these properties, one may anticipate its pharmacodynamic activity on lipids specifically related to lipid disorders(16) Picroside I has earlier been shown to be active in several models of liver toxicity(17). Extracts of roots and rhizomes of $P$. kurroa have shown hepatoprotective activity in diverse models of liver toxicity(18). P. kurroa and its active principles have been shown to have hydrocholeretic activity and to increase bile production(19). P. kurroa reduced the lipid content $(\mathrm{mg} / \mathrm{g})$ of the liver more significantly. Histopathology showed that the P. kurroa extract brought about a reversal of the fatty infiltration of the liver $(\mathrm{mg} / \mathrm{g})$ and a lowering of the number of hepatic lipids $(\mathrm{mg} / \mathrm{g})(20)$.

$P$. santalinus bark and heartwood are rich in flavonoids and defend the liver against chemicalinduced toxicity. an experimental Studies showed that aqueous $(45 \mathrm{mg} / \mathrm{mL})$ and ethanol $(30 \mathrm{mg} / \mathrm{mL})$ bark extracts of $P$. santalinus remodeled CCl4induced liver injury in rats(21). Some other studies revealed that potent compounds pterocarpol and cryptomeridiol, present in $P$. santalinus heartwood, targeted the HBx proteins of hepatitis B virus, and were thus reported as strong drug candidates(22) and found to possess significant protective effect against hepatotoxicity induced by carbon tetrachloride(23).

Murva has Deepan, Vishaghna, Anuloman, Amapachan, Shulaprashaman and Pittasaraka property. It also has anti-inflammatory, antibacterial, antimutagenic, anticancer and anti-pyretic action. Ayurvedic preparations of Guduchi are used in the treatment of Pandu (Anemia), Kamala (Jaundice) and rakta pradodhaj vikaras. A clinical study has shown that Guduchi plays a crucial role in the normalization of altered liver functions (ALT, AST). Tinospora cordifolia has shown antihepatotoxic activity in CCl4 induced liver injury, by normalizing the liver function as assessed by biochemical parameters (SGPT, SGOT, Serum alkaline 
phosphatase, serum bilirubin) and morphologically $(24,25)$.

\section{Conclusion}

In this clinical case study, the patient has shown good improvement symptomatically during the management of the cholelithiasis. With the help of Ayurvedic treatment protocol, the patient is free from $4.7 \mathrm{~mm}$ cholelithiasis within 2 months of treatment and also improvement was observed in symptoms like the heaviness of the abdomen, pain in the abdomen, and nausea. So, it indicates that except for the life-threatening condition of cholelithiasis (which requires surgical management) it can be managed with Ayurvedic medicines and can be avoided complications of cholelithiasis. Ayurvedic herbal medicines also helps in the normalizing the function of liver. So, it helps in the prevention of further stone formation chances.

\section{References}

1. Henryk Dancygier. Clinical hepatology: Principles and practice of hepatobiliary diseases, volume 2; Springer science and business media; 2009. P. 1459.

2. Lee, J Y; Keane, MG; Periera, S (June2015). "Diagnosis and treatment of gallstone disease". The Practitioner.259 (1783): 15-9,2.

3. Alan R. Gaby et al, Nutritional approaches to prevention and treatment of Gallstones, Alternative medicine review, Volume 14, Number 3, 2009. P. 258.

4. http/ www.halstedsurgery.org.

5. Rajgopal Shenoy. K, Anitha Nileshwar, Manipal Manual of Surgery, 3rd edition, 2010 pg. 468.

6. Barrett, Kim E. (2012). Ganong's review of medical physiology (24th ed.). New York: McGraw-Hill Medical. p. 512.

7. Guyton and Hall (2011). Textbook of medical physiology. U.S.: Saunders Elsevier.p.784.ISBN 978-1-4160-4574-8.

8. "Secretion of Bile and the Role of Bile Acids In Digestion". www.vivo.colostate.edu. Retrieved 2017-03-31.

9. Russell DW, Setchell KDR. Bile acid biosynthesis. Biochemistry. 1992;31(20):47374749.

10. Li, T., \& Chiang, J. Y. (2009). Regulation of bile acid and cholesterol metabolism by PPARs. PPAR research, 2009, 501739. https:// doi.org/10.1155/2009/501739

11. Qiao, T., Ma, R. H., Luo, X. B., Yang, L. Q., Luo, Z. L., \& Zheng, P. M. (2013). The systematic classification of gallbladder stones. PloS one, 8(10), e74887. https://doi.org/10.1371/ journal.pone. 0074887 .
12. Hari Sadashiv Shastri Paradakar. Ashtang Hridayam Sutrasthan 15/15. Chaukhambha Surbharati Prakashan; 2002, p. 235.

13. Antarkar DS, Tathed PS, Vaidya AB. A pilot phase II trial with Arogyawardhini and Punarnavadi kwath in viral hepatitis. Panminerva Med. 1978; 20:157-63

14. Gupta et al.: Consequences of $\mathrm{T}$. dioica on Biochemical and Haematological Indices Pharmacognosy Journal, Vol 10, Issue 4, Jul-Aug, 2018.

15. Ram A, Lauria P, Gupta R, Kumar P, Sharma VN. Hypocholesterolemic effects of Terminalia arjuna tree bark. J Ethnopharmacol. 1997; 55: 165-9.

16. Koolman AH, Bloks VW, Oosterveer MH, Jonas I, Kuipers F, Sauer PJ, et al. Metabolic responses to long-term pharmacological inhibition of CB1receptor activity in mice in relation to dietary fat composition. Int J Obes (Lond) 2010; 34:374-84.

17. Singh B, Rastogi RP. Chemical examination of Picrorhiza kurroa Part VI: Re-investigation of Kutkin. Indian J Chem. 1972; 10:29-31.

18. Pilankar PD. A study of hepatoprotective effects of some indigenous plants in experimental animals. Ph.D. Thesis. University of Mumbai. 1981.

19. Pandey VN, Chaturvedi GN. Effect of indigenous drug kutaki on bile after producing biliary fistula in dogs. Indian J Med Res. 1970; 5:1-24.

20. Shetty, S. N., Mengi, S., Vaidya, R., \& Vaidya, A. D. (2010). A study of standardized extracts of Picrorhiza kurroa Royle ex Benth in experimental nonalcoholic fatty liver disease. Journal of Ayurveda and integrative medicine, 1(3), 203-210. https://doi.org/ 10.4103/0975-9476.72622.

21. Manjunatha BK. Hepatoprotective activity of Pterocarpus santalinus L. f., an endangered plant. Indian J Pharmacol. 2006; 38:25-8.

22. Manjunatha BK, Amit R, Priyadarshini P, Paul K. Lead findings from Pterocarpus santalinus with hepatoprotective potentials through in silico methods. Int J Pharma Sci and Res. 2010; 7:26570 .

23. Manjunatha B K. Hepatoprotective activity of Pterocarpus santalinus L.f.,an endangered medicinal plant. Indian J Pharmacol 2006; 38:25-8.

24. Karkal Y R, Bairy L K. Safety of aqueous extract of Tinospora cordifolia in healthy volunteers: A double blind randomized placebo controlled study.Iranian Journal of Pharmacology \& Therapeutics. 2007;6:59-61.

25. Nagarkatti D S, Rege N, Desai N K, Dahanukar SA. Modulation of Kupffer cell activity by Tinospora cordifolia in liver damage. Journal of Postgraduate Medicine. 1994;40:65-7. 